\title{
An Analysis on the Control of Administrative Discretion
}

\author{
Xiaojian Feng* \\ School of Politics and Public Administration, Qingdao University Shandong Qingdao 266100, China.
}

Abstract:Administrative discretion means that administrative agencies can exercise their rights based on their own judgment and actual conditions when dealing with matters that are not authorized by the law or have not made detailed provisions. The existence of administrative discretion is not only the result of the expansion of administrative power,but also to adapt to administrative differences in different regions and departments, and to maintain social fairness and justice.However,the existence of rights leads to abuse and corruption, which requires the legislature to control the problem of excessive discretionary power from the source. The administrative law enforcement agency further improves the administrative reconsideration,strengthens the selection and supervision of the staff of the administrative agency,and the judicial agency improves the judicial review.

Keywords:administration; discretion; control

With the continuous development of modern economic life and the continuous increase of government functions,the fact that modern administration is relatively extensive and complex has increased the discretionary power enjoyed by government organizations, involving all aspects of social life.This conforms to the requirements of modern administration for efficiency and is also a way to achieve justice in individual cases. Therefore, the existence of administrative discretion has a positive meaning.

While the administrative discretion facilitates the administration of administrative organs and improves the administrative efficiency of administrative organs,there are also various problems.For example:the use of power for personal gain,discrimination treatment,first loss of fairness. This is not only against the purpose of administrative discretion,but also against the will of the law,resulting in corruption,causing duty crimes,damaging the legal rights of administrative counterparts, undermining social justice,damaging the image of the government,detrimental to social stability,and affecting the process of China's rule-of-law society.Therefore,it is necessary to make an in-depth study of discretion and strengthen the control of administrative discretion so that administrative organs can make reasonable use of power.

Based on the fact that administrative discretion to be abused for the control of administrative discretion has been on the agenda,for its control,simply is to prevent the abuse of power,on the other hand,is in order to make the administrative discretion can be efficient and reasonable operation within the framework of the law,improve the administrative efficiency,safeguard the legitimate rights and interests of administrative relative person.

\section{I.Legislation to control}

"What we need is a move of the government,but the government in maintaining its initiative at the same time,can't become a'wild ${ }^{[1] " i n ~ t h e ~ a c t u a l ~ c o n t r o l, w e ~ c a n ~ n e i t h e r ~ t o o ~ s t r i c t ~ m a n a g e m e n t ~ o f ~ a d m i n i s t r a t i v e ~ d i s c r e t i o n ~ i f ~ t h e ~ l a w ~ i n ~ d e t a i l ~ a l l ~ r u l e s, b a s i c ~}$ is impossible,because it is neither conforms to the complexity of the current administration, at the same time,we cannot predict the future events.At the same time, it should not be too loose.Giving administrative organs too loose administrative power is equivalent to giving them the key to abuse their power.Once the cage of power is opened,the consequences will be disastrous.

\section{II.Law enforcement control}

Law enforcement control is the central link in controlling the exercise of discretion.This process requires us to remind administrative agencies at any time during the exercise of discretion that they should use their rights reasonably and act in accordance with the rules. We also give some rights to administrative counterparts,so that they have the ability to defend their rights and no longer dare to speak out in anger.At the same time,we will improve the administrative review system.Administrative reconsideration refers to the act in which the administrative opposite party refuses to accept the decision made by the administrative organ,so he/she files an application to the administrative organ for reconsideration, which accepts the application,re-examines it and finally makes a reconsideration decision."If there is no such system as administrative review,no matter groups or individuals,no matter public authorities or private organizations, they may abuse their power ${ }^{[2]}$. Our country's administrative reconsideration system on the one hand,examine whether the administrative organs of the administrative action is illegal,on the other hand to review administrative behavior whether appropriate,compared with administrative litigation method,the supervision of the administrative

Copyright (C) 2020 Xiaojian Feng

doi: 10.18282/1-e.v9i4.1694

This is an open-access article distributed under the terms of the Creative Commons Attribution Non-Commercial License (http://creativecommons.org/licenses/by-nc/4.0/), which permits unrestricted non-commercial use, distribution, and reproduction in any medium, provided the original work is properly cited. 
reconsideration system is wider,program more concise,caused by the abuse of discretion in administrative authority improper or illegal behavior can change directly.

\section{III.Judicial control}

Since we want to ensure the lawful exercise of administrative discretion, it is natural to work hard on judicial control.At present, the rule of law in our country socialist construction has achieved initial results, the judicial organs need to strengthen the construction of function more,first of all, the administrative rationality principle shall be included in the scope of judicial review of judicial organs,it is well known that judicial review is now,we know that the most effective and fair manner,will include the rationality principle,judicial review from essentially play a role.Secondly,in handling cases in accordance with the law,on the basis of ensuring that citizens'legitimate rights and interests are not infringed,the legitimate rights and interests of administrative organs are safeguarded.Neither do we stand idly by,nor do we collude with administrative organs.Finally,to improve the power of judicial suggestion, that is to say, the judicial organs can put forward to the departments with jurisdiction through other forms,such as judicial suggestions, for the illegal and disorderly phenomena beyond the jurisdiction of their own power,or can not be corrected through litigation. Request management correction.

\section{IV.Strengthen the selection and supervision of administrative staff}

Administrative discretion is the administrative organ in accordance with the law, have the right,but the specific exercise of people is, the law enforcers of the said administrative organ for the exercise of power,law enforcement personnel with strong subjectivity and flexibility,so we should strengthen the management and training for the staff:first,improve the comprehensive quality of law enforcement personnel,both cultural level and ability,fundamentally improve their quality,make the law enforcement officers in the exercise of discretion can be affected by the quality. Therefore, it is necessary to improve the selection of law enforcement officials. On the one hand,candidates should be considered from various aspects and their abilities should be comprehensively evaluated. On the other hand,the training of staff should be strengthened and regular assessment should be conducted,so that every law enforcement officer can be prepared for danger in times of peace and realize the consequences of abuse of power from the bottom of his heart.Second:improve the legal awareness of law enforcement personnel,rights for the use of the people,firmly establish the rights derived from the people,the exercise of rights must conform to the provisions of the law,must protect the legitimate interests of the people as the premise. Third,we will improve the accountability mechanism so that law enforcement officials are afraid to abuse their power.

"In modern countries under the rule of law,the exercise of rights and control always go hand in hand ${ }^{[3]}$."At present,The exercise of administrative discretion has been quite extensive in China,but its control is not perfect enough.In order to effectively prevent the abuse of administrative discretion,relevant authorities should strengthen the all-round control of rights,not only improve procedural legislation from the legislative aspect,but also"establish an optimized,capable,clean and stable team"[4].Only in this way can abuse of power be prevented and the process of legalization be further promoted.

In the future legal system construction,I hope our legislative branch can enact more detailed laws, not necessarily involving all aspects but as detailed as possible.Law enforcement agencies should act in accordance with the law,achieve both efficiency and results,and safeguard the credibility of the government and the interests of the parties concerned.We will handle administrative cases fairly,openly and transparently,and improve the administrative review system. The selection of the staff is based on the legal qualification examination, and job training is gradually strengthened to improve the overall quality of the staff.Through all aspects of the improvement, gradually reduce abuse.

\section{References:}

[1]Wang Wuling,Ma Licheng(2000).Some Problems of Administrative Discretion[J].Journal of Hebei University,no.(6),pp.98102.

[2]Liu Mingbo(1990).Theory and Practice of Administrative Supervision abroad[M].Jinan:Shandong People's Publishing House. pp. 65 .

[3]Shen Fujun(1995).On Administrative Discretion and its Control[J].Politics and Law,no.05,pp.38-41.

[4]Lian Zhenlong(2017).Research on the Power Structure and Its Operating Mechanism of the Communist Party of China[D]. Lanzhou University. 